\title{
How Therapies Work in MucociliaryClearance (MCC)
}

\author{
Murray Grossan* \\ Graduation 1948 University of Georgia School of Medicine, USA
}

Submission: March 07, 2016; Published: March 16, 2017

*Corresponding author: Murray Grossan, Graduation 1948 University of Georgia School of Medicine, 8631 W 3rd St. Ste 440 East Los Angeles, Ca 90048, USA, Tel: 310659 1006; Email: drgrossan@yahoo.com

\section{Introduction}

Mucocliary Clearance refers to the system which employs cilia to move entrapped bacteria, dust, toxins and allergens out of the respiratory system. The purpose of this article is to describe factors that enhance, stimulate, and improve mucociliary clearance, and explain the mechanisms by which they do so. There are two parts: the outer gel area and the inner sol layer that contains the cilia. In the upper respiratory system, the gel is moved from the nasal/sinus area to the nasopharynx, then to the stomach. In the lower respiratory system, it is moved up the trachea to the throat, where it is swallowed, and inactivated by the stomach. The cilia move in synchrony in the inner sol layer. This movement moves the outer gel layer that contains goblet cells, mucin (glycoprotein), IgA, albumin, lactoferrin and lysozyme. Therapy may be directed to the cilia, or the gel layer or both [1-5].

Many of the therapies have been validated by performing the Saccharin Test. This consists of placing a particle of saccharin on the medial surface of the inferior turbinate, one $\mathrm{cm}$ posterior to the anterior end. Then the patient is asked to swallow every 30 seconds, until she tastes the sweet taste. It there is no response after an hour, place saccharin on the tongue to determine if the taste sense is viable. Normally the saccharin is tasted in $5-10$ minutes.

\section{Saccharin Test Times}

1-4 minutes: Acute Allergy

5-7 minutes: Normal MCC

9-15 minutes: Infection

16-28 minutes: Chronic Infection

$30+$ minutes: Irreversible poor MCC

This is a useful clinical test that can determine if MCC is impaired. It can be used to test a therapy. It is of particular value in identifying sources of MCC impairment, such as industrial products, inhaled solvents, Chromium, SO2, Hyperbaric Oxygen, and many others. Directing therapy to mucociliary clearance offers a system of therapy that is outside of culture, sensitivity and antibiotics. Therapies for MCC include:

a)Antibiotics: Added to Pulsed Irrigation. Mupirocin and most antibiotics have been used via Pulsed Irrigation. Lee reports, that after literature search, there is no specific study indicating effectiveness of adding antibiotis to simple irrigation, except personal reports.

b)Breathing Exercises: Deep breathing rhythmic exercises help most lower respiratory conditions.

c)Bronchodilators: Such as theophylin generally increase MCC.

d)Chicken Soup: Benefits by thinning mucus and enabling increased cilia movement. When compared with hot water itself, chicken soup definitely increased nasal mucus velocity and aided nasal airflow resistance.

e)Corticosteroids: Generally increase MCC.

f)Dornase alpha: (Pulmozyme) contains human deoxyribonucllease, an enzyme that selectively cleaves DNA. It hydrolyzes the DNA present in the mucus of CF paitents, which reduces the viscosity of mucus in the lungs.

g)Fluid Intake: Reduced intake of fluids will thicken mucus and thereby slow MCC. First thing to do for cold, sinusitis, or cough is to increase fluids.

h)Green Tea: Supplies epigallocatechin=3-gallate (EGCG) known for anti-inflammatory effects. EGCG suppress the gene and/or protein expression of inflammatory cytokines and inflammation related enzymes.

i)Humming: Chest thumping and vibration devices. Humming at a low tone - frequency -, such a "ooomm", sets the mucus in motion, to break up mucus bonds. The vibration assists cilia return to normal. In the chest, rhythmic thumping 
can similarly shake loose obstructive mucus. For therapy, humming should be for a period of at least two hours over a 24 hour period $[6,7]$.

j)Hypertonic Inhalation: Is used for Cystic Fibrosis to thin the thick mucus.

k)Jumping Jacks: The athletic movement with thumping helps break the mucus bonds.

1)Neti Pot: Is useful for thinning the thick mucus associated with sinusitis.

m)Proteolytic Enzymes: These include Papain and Bromelain. These thin mucus and reduce swelling. Ideally these are best melted in the buccal pouch to avoid stomach inactivation. Clear.ease ${ }^{\mathrm{TM}}$, is taken 1 QID, dissolve in buccal pouch. It is a measured Bromelain/Papain combination.

n)Pulsed Irrigation: Here the rate of pulsation is used to maximize normal cilia movement. In addition, a pulsed irrigation is more effective in thinning mucus. The steady flow of a motorized irrigation maximizes the Bernoulli effect, to withdraw sinus contents. Once MCC is restored to normal, there is no need to continue irrigation.

o)Steam Inhalation: With tongue extended - warmth speeds cilia movement; moisture helps thin the mucus.

p)Surfactants: University of Cincinnati- S.Isaacs - used Johnson Baby Shampoo 1\% and found it useful for removing biofilm.

q)Temperature: Cold air reduces CBF - cilia beat frequency. This is why colds and respiratory infections increase in winter; going directly from cold outside to classroom, allows bacteria to remain in the respiratory system. Better to warm the nose/chest by inhaling from the cupped hand before entering the crowded elevator.

\section{Conclusion}

Whether you are treating the thickened mucus or the impaired rate of cilia, most therapies directed to only the upper respiratory system also effect the other lower respiratory system. Significantly, when impaired MCC is improved, the need for systemic antibiotics may be significantly reduced. In our world of increased antibiotic resistant, this can be of major assistance to the health of the patient. The author has detailed the mechanisms by which MCC can be enhanced in order to insure better compliance of the doctor's recommendations. With greater compliance, comes better healing.

\section{References}

1. Grossan M (1994) Office measurement of nasal mucociliaryclearance. English: Otolaryngology 2(7).

2. Grossan M. The saccharin test of masalmucociliary function. The Eye Ear Nose.

3. Isaacs S, Fakhri S, Luong A, Whited C, Citardi MJ (2011) The effect of dilute Baby Shampoo on nasal mucociliary clearance in healthy subjects. Am J Rhinol Allergy 25(1): e27-29.

4. Lee JT, Chiu AG (2014) Topical anti-infective sinonasal irrigations: update and literature review. Am J Rhinol Allergy 28(1): 29-38.

5. Ohishi T, Goto S, Monira P, Isemura M, Nakamura Y (2015) Antiinflammatory action of Green Tea. Antiinflamm Antiallergy Agents Med Chem.

6. Saketkhoo K, Januszkiewicz A, Sackner MA (1978) Effects of drinking hotwater, cold water, chicken soup, on nasal mucus velocity and nasal airflow resistance. Chest 74(4): 408-410.

7. Schlosser RJ (2006) Surfactant and its role in chronic sinusitis. Ann OtolRhinolLaryngol Suppl 196: 40-44.

Your next submission with Juniper Publishers
will reach you the below assets
- Quality Editorial service
- Swift Peer Review
- Reprints availability
- E-prints Service
- Manuscript Podcast for convenient understanding
- Global attainment for your research
- Manuscript accessibility in different formats
( Pdf, E-pub, Full Text, Audio)
- Unceasing customer service
Track the below URL for one-step submission
https://juniperpublishers.com/online-submission.php

